\title{
PENGARUH SERVICE EXCELLENT TERHADAP KEPATUHAN FORMAL WAJIB PAJAK BADAN PADA KPP PRATAMA GRESIK
}

\author{
Lenny Jomeiria ${ }^{a}$ \\ Djoko Dewantoro ${ }^{b}$ \\ ${ }^{a}$ Sekolah Pascasarjana Universitas Airlangga ${ }^{b}$ Fakultas Ekonomi dan Bisnis Universitas Airlangga \\ Email: lennyjo@yandex.com ${ }^{a}$; djoko-d@feb.unair.ac.id ${ }^{b}$
}

ARTICLE HISTORY

Received:

19 Februari 2019

Revised

16 March 2019

Accepted:

1 April 2019

Online available:

14 Mei 2019

Keywords:

Service Excellent, Formal Taxpayer

Compliance,

Tax Office Primary

Gresik.

Kata Kunci:

Service Excellent, Kepatuhan Formal Wajib Pajak Badan, Kantor Pelayanan Pajak Pratama Gresik.

\section{ABSTRACT}

Introduction: The government has launched a program called Service Excellent to improve the quality of service to the community. Through this program, government officials are expected to provide the best service to the community through the skills, attitude, appearance, attention, action and responsibility and coordinated, as well as providing the best solutions for the needs of the community. In the marketing world, this process is called Service Excellent. One of the government agencies that are running Service Excellent is the Tax Office Primary Gresik. The Service Excellent formal compliance can affect corporate taxpayers effective Tax Office Primary Gresik.

Methods: Service Excellent in Tax Office Primary Gresik can be measured by physical evidence, reliability, responsiveness, assurance and empathy. The technique of collecting data through questionnaires. The analysis method used is multiple linear regression and hypothesis testing to determine the effect formal service excellent adherence corporate taxpayers. Analysis of the data used include validity test, reliability test, normality test, multicollinearity test, heterocedastisity test, autocorrelation test, and hypothesis testing (t test partial and $\mathrm{F}$ test simultaneous).

Results: The results of this study are variables simultaneously physical evidence, reliability, responsiveness, assurance and empathy influence the formal obedience corporate taxpayers, while only partial assurance and empathy variables that influence the formal obedience corporate taxpayers.

Conclusion and suggestion: Tax Office Primary Gresik should improve and pay more attention about variables simultaneously physical evidence, reliability, and responsiveness to achieve customer satisfaction with service excellent. 


\section{ABSTRAK}

Pemerintah telah mencanangkan suatu program yang disebut sebagai Pelayanan Prima untuk meningkatkan kualitas layanan kepada masyarakat. Melalui program ini, diharapkan aparatur pemerintah memberikan pelayanan yang terbaik kepada masyarakat melalui kemampuan, sikap, penampilan, perhatian, tindakan serta tanggung jawab yang baik dan terkoordinasi, serta memberikan solusi yang terbaik bagi kebutuhan masyarakat. Dalam dunia pemasaran, proses ini disebut dengan Service Excellent. Salah satu instansi pemerintah yang menjalankan Service Excellent adalah Kantor Pelayanan Pajak Pratama Gresik. Adapun Service Excellent dapat mempengaruhi kepatuhan formal wajib pajak badan yang efektif pada Kantor Pelayanan Pajak Pratama Gresik.

Service Excellent pada Kantor Pelayanan Pajak Pratama Gresik dapat diukur melalui bukti fisik, keandalan, daya tanggap, jaminan dan empati. Teknik pengumpulan data melalui kuesioner. Metode analisis yang digunakan adalah regresi linier berganda dan uji hipotesis untuk mengetahui pengaruh service excellent terhadap kepatuhan formal wajib pajak badan. Analisis data yang digunakan meliputi uji validitas, uji reliabilitas, uji normalitas, uji multikolinieritas, uji heterokedastisitas, uji autokorelasi, serta pengujian hipotesis (uji t parsial dan uji F simultan). Hasil penelitian ini adalah secara simultan variabel bukti fisik, keandalan, daya tanggap, jaminan dan empati berpengaruh terhadap kepatuhan formal wajib pajak badan sedangkan secara parsial hanya variabel jaminan dan empati yang berpengaruh terhadap kepatuhan formal wajib pajak badan.

\section{INTRODUCTION}

Tingkat harapan konsumen terhadap kualitas layanan organisasi berbeda-beda. Dengan pengorbanan seminimal mungkin, konsumen menuntut untuk memperoleh pelayanan yang paling memuaskan dan terbaik. Dalam rangka peningkatan kualitas layanan kepada masyarakat, pemerintah telah mencanangkan suatu program yang disebut sebagai Pelayanan Prima. Dalam dunia pemasaran, proses ini disebut dengan Service Excellent. Dalam penelitian ini, Service Excellent adalah upaya untuk memberikan kepuasan kepada wajib pajak dengan cara memberikan pelayanan pajak yang baik, sopan santun, ramah, tanggap, cermat dan cepat sesuai standar pelayanan pajak yang ditetapkan melalui Surat Edaran Direktorat Jenderal Pajak Nomor SE-84/PJ/2011. Service Excellent dalam penelitian ini diukur melalui bukti fisik, keandalan, daya tanggap, jaminan, dan empati pada Kantor Pelayanan Pajak Pratama Gresik.

Wajib Pajak adalah faktor penting yang menentukan keberhasilan atau kegagalan aktivitas pemungutan dan pengumpulan pajak untuk negara sehingga harus mendapatkan pelayanan yang terbaik. Namun pada kenyataannya, banyak wajib pajak yang menemui hambatan dalam proses pelayanan yang diberikan oleh petugas pajak, misalnya: petugas yang tidak ramah, lambat, antrian terlalu lama, fasilitas kantor dan layanan yang kurang memadai dan lain-lain yang menimbulkan keluhan dan berakibat pada adanya sikap tidak patuh dalam melaksanakan kewajiban perpajakan. Kewajiban 
perpajakan bagi wajib pajak adalah menyampaikan SPT Tahunan PPh. Berdasarkan data pelaporan SPT Tahunan PPh wajib pajak badan tahun 2010 pada KPP Pratama Gresik Utara yaitu sebesar 181. Sedangkan data pelaporan SPT Tahunan PPh wajib pajak badan tahun 2010 pada KPP Pratama Gresik Selatan yaitu sebesar 539.

Ketidakpatuhan wajib pajak badan atau penurunan kualitas layanan yang diterima oleh wajib pajak badan dapat menyebabkan wajib pajak badan tidak melaksanakan kewajiban perpajakannya dan berakibat pada penurunan kepatuhan dalam penyampaian kewajiban perpajakan (SPT Tahunan PPh) oleh wajib pajak badan. Salah satu upaya dalam meningkatkan kepatuhan wajib pajak adalah memberikan pelayanan yang baik kepada wajib pajak.

Berdasarkan data dari Kementerian Keuangan disebutkan bahwa KPP Madya Sidoarjo yang berada di bawah Kantor Wilayah (Kanwil) Jawa Timur II sebagai KPP Percontohan yang memperoleh juara III kantor pelayanan terbaik di lingkungan Kementerian Keuangan pada tahun 2010. Hal ini mendorong peneliti untuk menggali lebih dalam kualitas pelayanan prima di KPP lain yang masih berada di bawah Kantor Wilayah (Kanwil) Jawa Timur II sesuai dengan Surat Edaran Nomor 84/PJ/2011 tentang Pelayanan Prima. Namun, dalam penelitian ini hanya difokuskan pada KPP Pratama Gresik saja dan tidak meneliti KPP lain yang berada di bawah Kantor Wilayah (Kanwil) Jawa Timur II.

\section{LITERATURE REVIEW}

\section{The traditional society}

\section{Kualitas}

Menurut Parasuraman et.al. (1985) ada lima dimensi kualitas jasa yaitu sebagai berikut:

1. Keandalan (Reliability) yaitu kemampuan untuk melaksanakan jasa yang dijanjikan dengan terpercaya dan akurat.

2. Daya Tanggap (Responsiveness) yaitu kemauan untuk membantu pelanggan dan memberikan pelayanan jasa dengan cepat.

3. Kepastian (Assurance) meliputi pengetahuan dan sopan santun karyawan serta kemampuan karyawan untuk menanamkan kepercayaan dan keyakinan pada pelanggan terhadap perusahaan.

4. Empati (Empathy) yaitu kepedulian dan perhatian secara individual yang diberikan perusahaan kepada pelanggan.

5. Berwujud (Tangibles) meliputi fasilitas fisik, personil, dan peralatan untuk komunikasi.

\section{Service Excellent}

Service Excellent adalah upaya untuk memberikan kepuasan kepada pelanggan dengan cara memberikan pelayanan yang baik, sopan, ramah, dan tepat waktu yang 
dilakukan dengan tulus dan terus menerus sesuai standar pelayanan yang dapat dipertanggungjawabkan.

\section{Kepatuhan Wajib Pajak}

Menurut Nurmantu (2005) terdapat dua macam kepatuhan yaitu: kepatuhan formal dan kepatuhan material. Kepatuhan formal adalah suatu keadaan dimana wajib pajak memenuhi kewajiban perpajakan secara formal sesuai dengan ketentuan dalam undang-undang perpajakan. Apabila wajib pajak badan telah melaporkan Surat Pemberitahuan Pajak Penghasilan (SPT PPh) Tahunan sebelum atau pada tanggal 30 April maka wajib pajak badan telah memenuhi ketentuan formal. Wajib pajak yang memenuhi kepatuhan material adalah wajib pajak yang mengisi dengan jujur, baik, dan benar Surat Pemberitahuan (SPT) sesuai ketentuan dalam Undang-Undang Pajak Penghasilan (PPh) dan menyampaikan ke KPP sebelum batas waktu berakhir. Dalam penelitian ini menggunakan kepatuhan formal wajib pajak badan.

\section{Previous Study and Hypothesis}

1. Ha: Bukti fisik, keandalan, daya tanggap, jaminan dan empati berpengaruh positif terhadap kepatuhan formal wajib pajak badan secara simultan

2. Ha: Bukti fisik, keandalan, daya tanggap, jaminan dan empati berpengaruh positif terhadap kepatuhan formal wajib pajak badan secara parsial

\section{RESEARCH METHODS}

Populasi dalam penelitian ini diambil dari data KPP Pratama Gresik yaitu wajib pajak badan efektif dan melaporkan SPT Tahunan PPh pada KPP Pratama Gresik tahun 2010 sebanyak 181 Wajib Pajak Badan Gresik Utara dan 539 Wajib Pajak Badan Gresik Selatan. Penentuan sampel dari penelitian ini dengan incidental sampling. Jumlah responden yang menjadi sampel dalam penelitian ini adalah sebagai berikut:

1. 65 perusahaan yang berada di wilayah kerja KPP Pratama Gresik Utara

2. 85 perusahaan yang berada di wilayah kerja KPP Pratama Gresik Selatan

Teknik yang digunakan dalam penelitian ini adalah kuesioner. Pengukuran variabel penelitian menggunakan skala Likert yang dimodifikasi untuk memberi nilai bagi jawaban wajib pajak badan. Teknik analisis yang digunakan adalah regresi linier berganda. Dalam penelitian ini variabel bebas dan variabel terikat akan diuji kualitas data meliputi uji validitas dan uji reliabilitas serta diuji asumsi klasik yang meliputi uji normalitas, uji heterokedastisitas, uji autokorelasi, uji multikolinieritas. 


\section{RESULT AND ANALYSIS}

\section{Uji Validitas Data}

Uji validitas menggunakan korelasi Pearson. Jika Pearson Correlation antara masing-masing pertanyaan dengan skor total menghasilkan nilai signifikansi $<0.05$ ( $\alpha=$ $5 \%)$, maka item pertanyaan dinyatakan valid. Berikut ini hasil uji validitas variabel independen dan variabel dependen:

Tabel 1

Nilai Uji Validitas Datas

\begin{tabular}{|l|c|c|c|}
\hline \multicolumn{1}{|c|}{ Pertanyaan } & $\begin{array}{c}\text { Nilai } \\
\text { Korelasi }\end{array}$ & Signifikansi & Keterangan \\
\hline Bukti Fisik (X1) & & & \\
\hline X11 & 0.541 & 0.000 & Valid \\
\hline X12 & 0.639 & 0.000 & Valid \\
\hline X13 & 0.660 & 0.000 & Valid \\
\hline X14 & 0.633 & 0.000 & Valid \\
\hline X15 & 0.589 & 0.000 & Valid \\
\hline X16 & 0.684 & 0.000 & Valid \\
\hline X17 & 0.613 & 0.000 & Valid \\
\hline X18 & 0.609 & 0.000 & Valid \\
\hline Keandalan (X2) & & & \\
\hline X21 & 0.796 & 0.000 & Valid \\
\hline X22 & 0.875 & 0.000 & Valid \\
\hline X23 & 0.816 & 0.000 & Valid \\
\hline X24 & 0.829 & 0.000 & Valid \\
\hline Daya Tanggap (X3) & & & \\
\hline X31 & 0.804 & 0.000 & Valid \\
\hline X32 & 0.801 & 0.000 & Valid \\
\hline X33 & 0.810 & 0.000 & Valid \\
\hline Jaminan (X4) & & & \\
\hline X41 & 0.787 & 0.000 & Valid \\
\hline X42 & 0.841 & 0.000 & Valid \\
\hline X43 & 0.800 & 0.000 & Valid \\
\hline X44 & 0.825 & 0.000 & Valid \\
\hline Empati (X5) & & & \\
\hline X51 & 0.814 & 0.000 & Valid \\
\hline X52 & 0.802 & 0.000 & Valid \\
\hline X53 & 0.870 & 0.000 & Valid \\
\hline Kepatuhan Formal Wajib Pajak Badan (Y) & & & \\
Y11 & 0.902 & 0.000 & Valid \\
\hline Y12 & 0.927 & 0.000 & Valid \\
\hline Y13 & 0.894 & 0.000 & Valid \\
\hline & 0.912 & 0.000 & Valid \\
\hline & & & \\
\hline & & & \\
\hline
\end{tabular}

Sumber: Data Diolah 


\section{Uji Reliabilitas Data}

Reliabilitas menunjukkan stabilitas dan konsistensi dari pengukurnya. Untuk mengukur reliabilitas digunakan nilai Cronbach Alpha. Jika nilai Cronbach Alpha $>0.6$, maka semua item pertanyaan untuk masing-masing variabel penelitian dinyatakan reliabel. Berikut ini hasil uji reliabilitas variabel independen dan variabel dependen:

\section{Uji Asumsi Klasik}

Tabel 2

Hasil Uji Asumsi Klasik

\begin{tabular}{|l|c|c|c|}
\hline \multicolumn{1}{|c|}{ Variabel Penelitian } & $\begin{array}{c}\text { Cronbach } \\
\text { Alpha }\end{array}$ & Nilai Kritis & Keterangan \\
\hline Bukti Fisik (X1) & 0.761 & 0.6 & Reliabel \\
\hline Keandalan (X2) & 0.849 & 0.6 & Reliabel \\
\hline Daya Tanggap (X3) & 0.832 & 0.6 & Reliabel \\
\hline Jaminan (X4) & 0.828 & 0.6 & Reliabel \\
\hline Empati (X5) & 0.772 & 0.6 & Reliabel \\
\hline Kepatuhan Formal Wajib Pajak Badan (Y) & 0.930 & 0.6 & Reliabel \\
\hline
\end{tabular}

Uji asumsi klasik yang harus dipenuhi untuk memperoleh model regresi yang baik adalah normalitas, non multikolinieritas, non heterokedastisitas, dan non autokorelasi.

a. Normalitas

Pengujian normalitas residual dilakukan dengan menggunakan normal probability plot. Dalam penelitian ini, titik-titik terkumpul di sekitar garis lurus, sehingga disimpulkan residual model regresi mengikuti distribusi normal.

b. Multikolinieritas

Multikolinieritas dapat diuji dengan menggunakan nilai Variance Inflation Factor (VIF) dan Tolerance (TOL). Jika nilai VIF $>10$ atau nilai Tol $<0,1$ maka terdapat multikolinieritas. Namun, jika nilai VIF $<10$ atau nilai Tol $>0,1$ maka tidak terdapat multikolinieritas (Ghozali:2005). Berikut ini hasil uji multikolinieritas:

Tabel 3

Hasil Uji Multikolinieritas

\begin{tabular}{|c|c|c|}
\hline Variabel Independen & Tolerance & VIF \\
\hline Bukti Fisik (X1) & 0.503 & 1.988 \\
\hline Keandalan (X2) & 0.409 & 2.446 \\
\hline Daya Tanggap (X3) & 0.482 & 2.076 \\
\hline Jaminan (X4) & 0.363 & 2.758 \\
\hline Empati (X5) & 0.384 & 2.603 \\
\hline
\end{tabular}

Sumber: Data Diolah 
Berdasarkan hasil hasil uji multikolinieritas di atas maka tidak terdapat multikolinieritas.

c. Heterokedastisitas

Berdasarkan Tabel 4, signifikansi tiap-tiap variabel independen pada tabel Coefficients $^{a}$ lebih dari alpha (5\%) maka tidak terdapat heterokedastisitas.

Tabel 4

Hasil Uji Heterokedastisitas

\begin{tabular}{|c|c|c|c|c|c|c|}
\hline \multirow{2}{*}{\multicolumn{2}{|c|}{ Model }} & \multicolumn{2}{|c|}{ Unstandardized Coefficients } & \multirow{2}{*}{$\begin{array}{c}\begin{array}{c}\text { Standardized } \\
\text { Coefficients }\end{array} \\
\text { Beta }\end{array}$} & \multirow[b]{2}{*}{$\mathrm{T}$} & \multirow[b]{2}{*}{ Sig. } \\
\hline & & B & Std. Error & & & \\
\hline \multirow[t]{6}{*}{1} & (Constant) & .351 & .176 & & 1.991 & .048 \\
\hline & MEAN_X1 & -.101 & .077 & -.151 & -1.306 & .194 \\
\hline & MEAN_X2 & -.004 & .070 & -.007 & -.051 & .960 \\
\hline & MEAN_X3 & -.024 & .056 & -.051 & -.429 & .668 \\
\hline & MEAN_X4 & .005 & .080 & .009 & .064 & .949 \\
\hline & MEAN_X5 & .117 & .066 & .234 & 1.767 & .079 \\
\hline
\end{tabular}

Sumber: Data Diolah

\section{d. Autokorelasi}

Tabel 5

Hasil Uji Autokorelasi

\begin{tabular}{|c|c|c|c|c|c|c|c|c|c|c|}
\hline & & & & Model S & Immary & & & & & \\
\hline \multirow[b]{2}{*}{ Model } & \multirow[b]{2}{*}{$\mathrm{R}$} & \multirow[b]{2}{*}{ R Square } & \multirow[b]{2}{*}{$\begin{array}{l}\text { Adjusted } \\
\text { R Square }\end{array}$} & \multirow[b]{2}{*}{$\begin{array}{l}\text { Std. Error of } \\
\text { the Estimate }\end{array}$} & \multicolumn{5}{|c|}{ Change Statistics } & \multirow[b]{2}{*}{$\begin{array}{l}\text { Durbin- } \\
\text { Watson }\end{array}$} \\
\hline & & & & & $\begin{array}{c}\text { R Square } \\
\text { Change }\end{array}$ & F Change & df1 & $\mathrm{df} 2$ & $\begin{array}{l}\text { Sig. F } \\
\text { Change }\end{array}$ & \\
\hline 1 & $.458^{\mathrm{a}}$ & .209 & .182 & .399 & .209 & 7.629 & 5 & 144 & .000 & 2.103 \\
\hline
\end{tabular}

a. Predictors: (Constant), MEAN_X5, MEAN_X1, MEAN_X3, MEAN_X2, MEAN_X4

b. Dependent Variable: MEAN_Y1

Sumber: Data Diolah

Kriteria Pengujian Autokorelasi

\begin{tabular}{|l|l|}
\hline$\left(4-d_{L}\right)<D W<4$ & Ho ditolak, terdapat autokorelasi \\
\hline$\left(4-d_{U}\right)<D W<\left(4-d_{L}\right)$ & Ragu-ragu \\
\hline$d_{U} \quad<D W<\left(4-d_{U}\right)$ & Ho diterima, tidak terdapat autokorelasi \\
\hline$d_{L} \quad<D W<d_{U}$ & Ragu-ragu \\
\hline $0 \quad<D W<d_{L}$ & Ho ditolak, terdapat autokorelasi \\
\hline
\end{tabular}

Berdasarkan tabel Durbin-Watson (DW) untuk variabel independen $(k=5)$ dan total sampel $(n=150)$ menunjukkan bahwa $d_{U}=1.8024$. 
Oleh karena $d_{U}<D W<\left(4-d_{U}\right)$ adalah $1.8024<2.103<(4-1.8024)$ maka H0 diterima, tidak terdapat autokorelasi.

\section{Uji F (simultan)}

Uji $\mathrm{F}$ dilakukan untuk mengetahui ada atau tidak ada pengaruh antara variabel bukti fisik (X1), keandalan (X2), daya tanggap (X3), jaminan (X4), dan empati (X5) secara simultan terhadap variabel kepatuhan formal wajib pajak badan (Y). Berikut hasil signifikansi uji F:

Tabel 6

Hasil Uji F

\begin{tabular}{|ll|r|r|r|r|c|}
\hline Model & & Sum of Squares & \multicolumn{1}{|c|}{ Df } & Mean Square & F & Sig. \\
\hline 1 & Regression & 6.083 & 5 & 1.217 & 7.629 & $.000^{\mathrm{a}}$ \\
& Residual & 22.965 & 144 & .159 & & \\
& Total & 29.048 & 149 & & & \\
\hline
\end{tabular}

a. Predictors: (Constant), MEAN_X5, MEAN_X1, MEAN_X3, MEAN_X2, MEAN_X4

b. Dependent Variable: MEAN_Y1

Sumber: Data Diolah

\section{Uji t (parsial)}

Uji t tujuannya untuk mengetahui ada atau tidak ada pengaruh antara variabel independen $(X)$ secara parsial terhadap variabel dependen $(Y)$. Berikut hasil signifikansi uji t:

Tabel 7

Hasil Uji t

\begin{tabular}{|c|c|c|c|c|c|c|}
\hline \multirow{2}{*}{\multicolumn{2}{|c|}{ Model }} & \multicolumn{2}{|c|}{ Unstandardized Coefficients } & \multirow{2}{*}{$\begin{array}{c}\text { Standardized } \\
\text { Coefficients }\end{array}$} & \multirow[b]{2}{*}{$\mathrm{T}$} & \multirow[b]{2}{*}{ Sig. } \\
\hline & & B & Std. Error & & & \\
\hline \multirow[t]{6}{*}{1} & (Constant) & 1.715 & .338 & & 5.079 & .000 \\
\hline & MEAN_X1 & -.029 & .148 & -.020 & -.196 & .845 \\
\hline & MEAN_X2 & -.185 & .134 & -.161 & -1.388 & .167 \\
\hline & MEAN_X3 & .078 & .107 & .078 & .733 & .465 \\
\hline & MEAN_X4 & .375 & .154 & .300 & 2.438 & .016 \\
\hline & MEAN_X5 & .276 & .127 & .261 & 2.180 & .031 \\
\hline
\end{tabular}

\section{Pembahasan Hasil Penelitian}

Berdasarkan hasil uji F menunjukkan nilai signifikansi $F$ sebesar 0.000 lebih kecil dari nilai alpha (0.05) dan hasil uji nilai $F$ sebesar 7.629, maka dapat disimpulkan bahwa service excellent meliputi bukti fisik (X1), keandalan (X2), daya tanggap (X3), jaminan 
(X4), dan empati (X5) secara simultan berpengaruh terhadap kepatuhan formal wajib pajak badan pada KPP Pratama Gresik.

Berdasarkan hasil uji t, variabel bukti fisik memiliki t hitung yaitu sebesar $-0.196<$ $t$ tabel 1.655. Berdasarkan hasil tersebut dapat disimpulkan bahwa variabel bukti fisik (X1) secara parsial tidak berpengaruh signifikan terhadap kepatuhan formal wajib pajak badan (Y). Ketidaksignifikannya variabel bukti fisik dapat disebabkan oleh banyaknya metode pelaporan SPT Tahunan (PPh) yang dapat dilakukan wajib pajak badan. Beberapa metode pelaporan SPT Tahunan (PPh) meliputi e-SPT, drop box, dan pos.

Berdasarkan hasil uji t, variabel keandalan memiliki t hitung yaitu sebesar -1.388 $<\mathrm{t}$ tabel 1.655. Berdasarkan hasil tersebut dapat disimpulkan bahwa variabel keandalan (X2) secara parsial tidak berpengaruh signifikan terhadap kepatuhan formal wajib pajak badan $(\mathrm{Y})$.

Berdasarkan hasil uji t, variabel daya tanggap (X3) t hitung yaitu sebesar $0.733<\mathrm{t}$ tabel 1.655. Berdasarkan hasil tersebut dapat disimpulkan bahwa variabel daya tanggap (X3) secara parsial tidak berpengaruh signifikan terhadap kepatuhan formal wajib pajak badan (Y). Ketidaksignifikannya variabel daya tanggap disebabkan oleh banyaknya jumlah wajib pajak yang efektif di KPP Pratama Gresik sedangkan jumlah petugas pajak yang memberikan pelayanan perpajakan jumlahnya sedikit. Hal ini mengakibatkan pelayanan perpajakan yang diberikan menjadi tidak optimal, lamban dan kurang tanggap.

Berdasarkan hasil uji t, variabel jaminan (X4) memiliki t hitung yaitu sebesar 2.438 $>t$ tabel 1.655. Berdasarkan hasil tersebut dapat disimpulkan bahwa variabel jaminan (X4) secara parsial berpengaruh signifikan terhadap kepatuhan formal wajib pajak badan (Y).

Berdasarkan hasil uji t, variabel empati (X5) memiliki t hitung yaitu sebesar 2.180 $>\mathrm{t}$ tabel 1.655. Berdasarkan hasil tersebut dapat disimpulkan bahwa variabel empati (X5) secara parsial berpengaruh signifikan terhadap kepatuhan formal wajib pajak badan $(\mathrm{Y})$.

\section{CONCLUSION}

Berdasarkan analisis dan pembahasan maka dapat disimpulkan sebagai berikut:

1. Variabel bukti fisik, keandalan, daya tanggap, jaminan dan empati sebagai gambaran service excellent secara simultan berpengaruh signifikan terhadap kepatuhan formal wajib pajak badan.

2. Variabel bukti fisik, keandalan, dan daya tanggap secara parsial tidak berpengaruh signifikan terhadap kepatuhan formal wajib pajak badan.

3. Variabel jaminan dan empati secara parsial berpengaruh signifikan terhadap kepatuhan formal wajib pajak badan. 


\section{Lenny Jomeiria}

4. Berdasarkan uji Koefisien Determinasi (Adjusted $R^{2}$ ) dibuktikan bahwa pengaruh bukti fisik (tangible), keandalan (reliability), daya tanggap (responsiveness), jaminan (assurance), dan empati (empathy) terhadap kepatuhan formal wajib pajak badan adalah sebesar $20.9 \%$ sedangkan sisanya yaitu $79.1 \%$ dipengaruhi oleh variabel lain di luar penelitian ini.

\section{REFERENCES}

Chaniago, Junaidi. 2010. Tabel Durbin-Watson (DW), $\alpha=5 \%$, Diakses dari http://junaidichaniago.com/2010/04/24/download-tabel-durbin-watson-dw lengkap/ pada tanggal 10 Oktober 2012 pukul 15.46 WIB.

Endista, Amiyella. 2008. Teknik Pengambilan Sampel. Diakses dari http://berandakami.files.wordpress.com/2008/10/teknik-pengambilansampel.pdf pada tanggal 19 Februari 2013 pukul 21.50 WIB.

Ghozali, Imam. 2005. Aplikasi Analisis Multivariate dengan Program SPSS. Semarang: Badan Penerbit Universitas Diponegoro.

Nurmantu, Safri. 2005. Pengantar Perpajakan Edisi Ketiga. Jakarta: Granit.

Parasuraman,A., and Valarie A. Zeithaml, and Leonard L. Berry. 1985. A Conceptual Model of Service Quality and its Implications for Future Research. Journal of Marketing Vol. 49: 41-50.

Sukarno, Gendut dan Lia Nirawati. 2007. Kontribusi Kualitas Pelayanan Terhadap Kepuasan Pembayar Pajak. Jurnal NeO-Bis Vol.1 No. 2: 71-87.

Surat Edaran Direktur Jenderal Pajak Nomor: SE-84/PJ/2011 tanggal 15 November 2011 tentang Pelayanan Prima. 